\title{
特集／新しい医療用レーザー装置とその特性
}

\section{PDT用半導体レーザ治療装置 Diode Laser System for PDT}

\author{
金田 明, 猪 吉輝 \\ 松下産業機器株式会社産業機器研究所 \\ T561 大阪府豊中市稲津町 3-1-1 \\ TEL : 06-866-8526 FAX : 06-862-3004
}

\begin{abstract}
Akira KANEDA and Yoshiteru I I
Matsushita Industrial Equipment Co., Ltd Industrial Equipment Reserch Laboratory 1-1,3Chome, Inazu-Cho, Toyonaka, Osaka
\end{abstract}

\begin{abstract}
要 旨
光化学療法 (Photodynamic Therapy：以下PDTと称す) 用のレーザ光源として、半導体 レーザ治療装置を開発した。PDTは患者に対する体力的負担や副作用が少ないことからこれ から迎える高龄化社会に適応した療法であるといわれている。しかしレーザ条件(波長, 出力) の問題から普及のための手ごろなレーザ装置が無く，その開発が待ち望まれていた。今回我々 が開発したレーザ装置は，小型・軽量であり操作が簡単等，これらの要望を满たしたものであ りPDTの普及の一助之なるものと期待する。

キーワード：半導体レーザ，光化学療法 (PDT), NPe 6, 癌
\end{abstract}

\begin{abstract}
We developed a diode laser system as a laser light source for Photodynamic Therapy (PDT).PDT is considered as a suitable therapy for the coming aging society since it gives less burden to body or has less side effects. Due to laser condition problems, such as wavelength and output, there was no suitable laser system to popularize PDT and such system was eagerly awaited to be developed. Today, the laser system we newly developed was small and light weighted system with easy operation. Such features will satisfy the needs for PDT and may help to popularize PDT.
\end{abstract}

Key words : Diode laser, Potodynamic Therapy (PDT), NPe 6, Cancer

\section{1.はじめに}

厚生省の統計による疾患別死亡人口の推移（図 1）に よると，墨性新生物（以下癌と称す）による死亡が年々 增加の一途を辿っている。さらに，大阪府立成人病セン ターの分析によると図 2 に示す通り癌の発生部位別患者
数の予測は, 危惧すべき傾向を示している。つまり喫煙 による肺癌の增加之食生活の欧米化による結腸・直腸癌 の增加が予測されている。特に肺癌は再発・多発性が強 いうえに再手術が出来ないケースがあり, 治療上最も困 難な症例の一つである。 


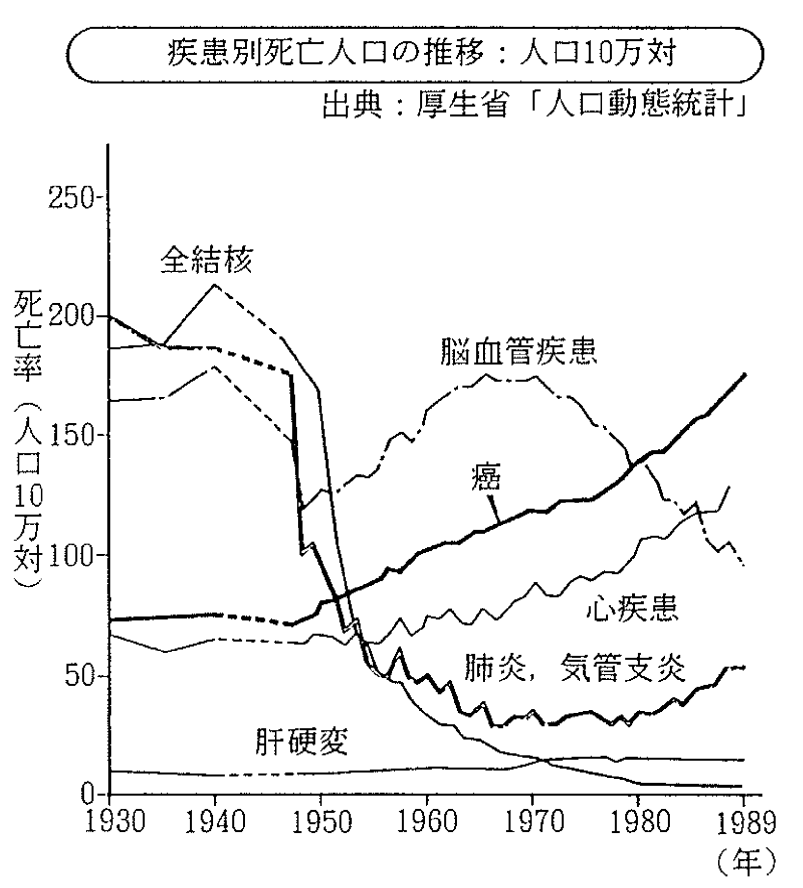

図 1 主要死因別にみた死亡率

一方, 高齢化に伴い体力的に手術が出来ない患者の増 加も著しく，外科手術以外に患者の体力的負担や副作用 の少ない治療の開発が待ち望まれている。

以上の社会的背景に鑑み, 当社は最近注目されつつあ るPDT"に着目し，当該療法に必要とされるコンパク トで使いやすい医用レーザ装置の開発に取り組んだ。

\section{PDTとレーザ装置}

$\mathrm{PDT}$ とは腫湟に親和性のある光感受性物質を患者の 静脈より投与し，腫瘍部に選択的に集積した段階で光感 受性物質の吸収波長に適合した光を腫激部に照射するこ とにより，光感受性物質を励起させ，その結果得られる 活性酸素の殺細胞作用により癌細胞を死隇させる療法の ことである。従って光感受性物質の集積部以外，或いは レーザ照射部以外の生体に対する障害性は極めて少ない。 また，それぞれ単独使用（薬剤，レーザ光）による副作 用も少ない撚法である。

このPDTに用いられるレーザ装置は少なくとも下記 4 点の条件を満たす必要がある。

1）光感受性物質の吸収波長に適合すること。

2) 治療面積, 治療時間等から判断して最低 $300 \mathrm{~mW}$ のレーザパワーが必要。

3）ファイバ導光により内視鏡治療が行えること。

4）安定したレーザ光を供給できること。

なお、今回の装置開発は数多くある光感受性物質の中 から，排泄時間が早く吸収帯波長が $664 \pm 4 \mathrm{~nm}$ と比較 的長いMONO-L-ASPARTYL CHLORIN e6（以下N
年間の癌患者数 2015 年 : 75 万人と推定

出典 : 大阪府立成人病センター

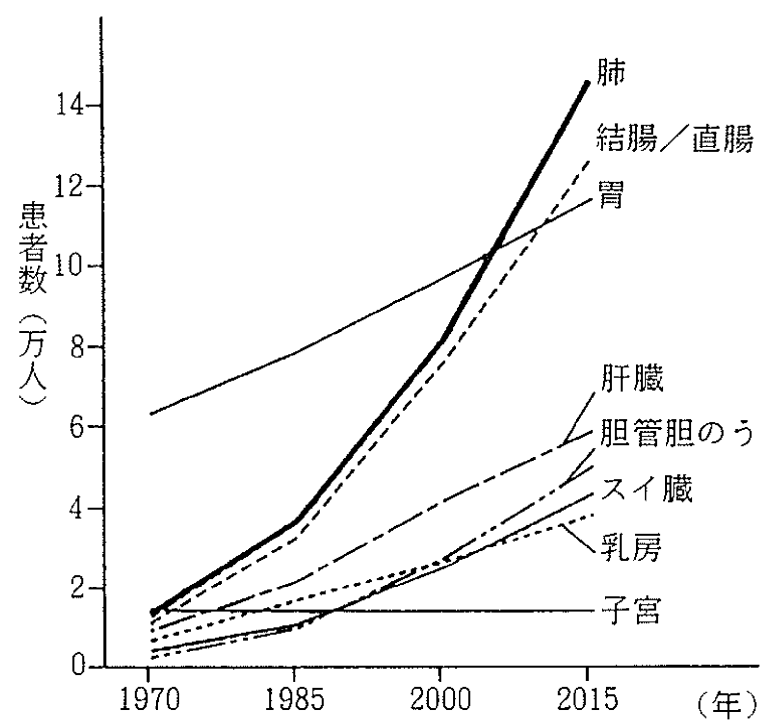

図 2 癌患者数の推移と予測

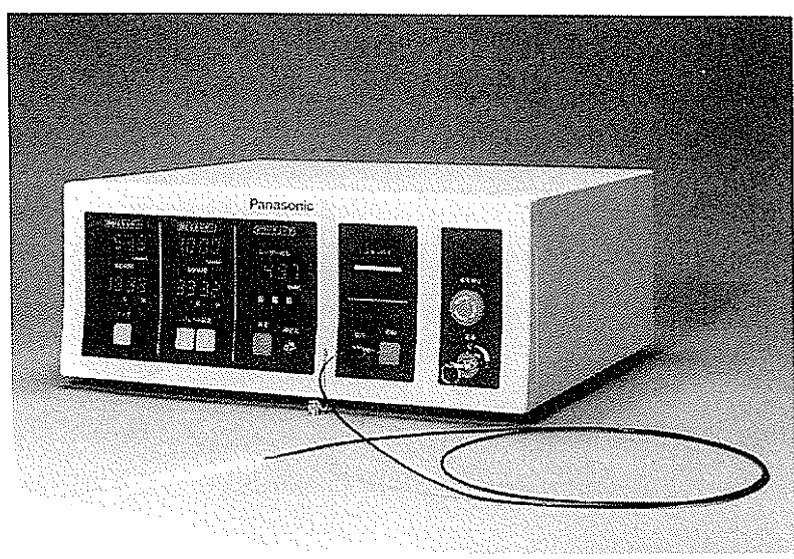

図 3 半導体レーザ装置の外観写真

Pe 6 と称す $)^{21}$ を選択し，この薬剤との組み合わせによ るPDTを目標とした。

\section{3 、装置の概要}

本装置の外観写真を図 3 に示す。外観写真からも分か るように本装置は小型・軽量である。（W490 mm $\times$ D 4 $15 \mathrm{~mm} \times \mathrm{H} 205 \mathrm{~mm}, 25 \mathrm{~kg}$ )。更に, 操作は全て本体の前 面パネル上で行うことができ，設定した条件や必要な情 報が表示される等, 操作性に優れた構成となっている。 一方，安全性を高めるため電源スイッチはキースイッチ を採用し，管理者以外使用出来ない上うにしている。ま た，非常時には非常停止スイッチにより緊急停止するこ とができる。レーザ光患部への導光は，前面パネル上の コネクター部に接続した光プローブにより導光される。

\section{1 装置の構成}

本装置の構成は図 4 の様になっている。図に示す如く 


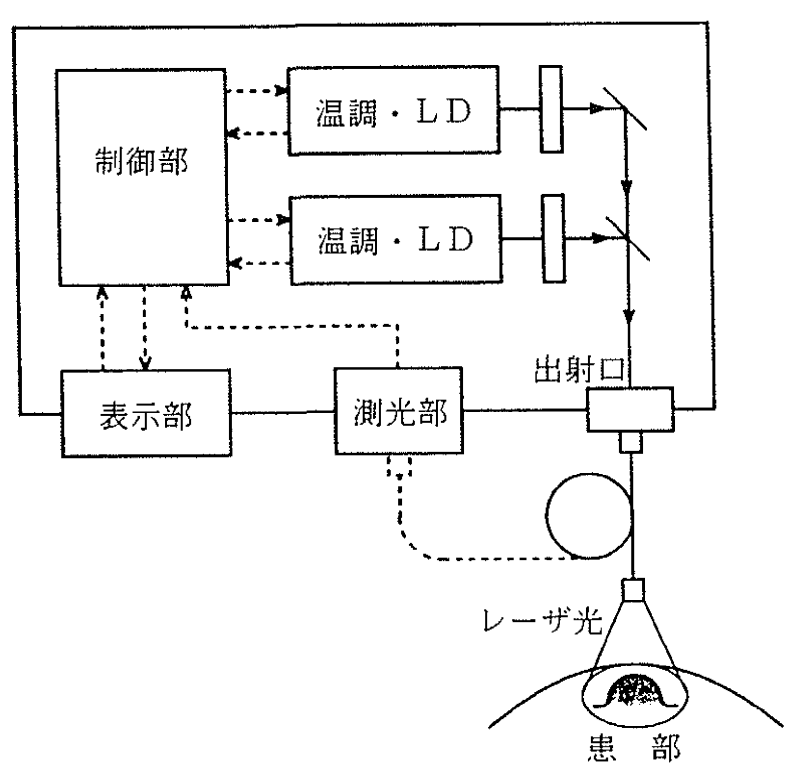

図 4 構 成 図

本装置は複数の半導体レーザユニットとこれらの動作を 制御する制御部, 各半導体レーザユニットからのレーザ 光を集光する集光部，プローブ先端のレーザ出力を測定 する測光部，照射条件等を入力・表示する入力・表示部 から構成されている。また，光源となる半導体レーザユ ニットは半導体レーザ素子（LD）と，その発振波長を 制御するための温度調節器（温調：電子冷却素子他）氻 ら構成されている。

\section{2 装置の機能}

本装置は，確実な治療を行うために二つの補償機能を 满えている。その一つ目は出力チェック機能であり,レー ザ素子や光プローブのトラブル及び出射端の污机等によ る出射端からのレーザ光出力の低下を，内蔵している光 センサーにより事前にチェックすることができる。ここ で読み取られたレーザ光出力が基集になり治療の条件が 設定される。二つ目は照射中のレーザ素子のトラブルに 対する補償である。治療中のレーザ荸子のトラブルによ る治療不足を解決するために, 個々のレーザ素子の発振 状態（レーザ光出力，波長）を監視し異常が検出されれ ば直ちに異常素子の運転を停止すると同時に残された素 子による照射条件を再設定し，治療が継続されるように なっている。

\section{3 仕様及び特長}

本装置の仕様を表 1 に示す。前述した通り本装圈は

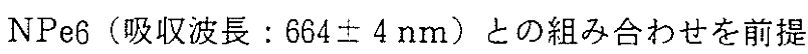
としており，中心波長を $664 \mathrm{~nm}$ に設定している。また， レーザ光出力は最大 $500 \mathrm{~mW}$ であるが設定スイッチによ

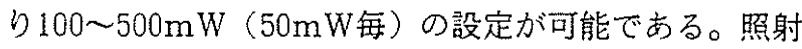
エネルギ量は50〜1000 J の間で選択が可能であり，設定
表 1 仕様

\begin{tabular}{|c|c|}
\hline 波 & $\begin{array}{l}\text { 中心波長 : } 664 \mathrm{~nm} \\
\text { 制御精度 : } \pm 0.2 \mathrm{~nm} \\
\text { 半值 幅 : MAX2nm }\end{array}$ \\
\hline 力 & $500 \mathrm{~mW}$ (プローブ出力) \\
\hline 照射モード & $\mathrm{CW} / \mathrm{PULSE}$ \\
\hline 設定ジュール & $50 \sim 1000 \mathrm{~J}$ \\
\hline 尊 光 路 & 石英ファイバ (コア径 $400 \mu \mathrm{m})$ \\
\hline 電 & $\mathrm{AC} 100 \mathrm{~V} \quad 3 \mathrm{~A}$ \\
\hline
\end{tabular}

出力と設定照射エネルギにより照射時間が自動的に設定 され管理される。導光ファイバは石英ファイバ(コア径 $400 \mu \mathrm{m})$ を使用しており内視鏡亡組み合わせて使用する ことが可能である。

また，本装置の特長として，小型・軽量は言うまでも なく，操作上の面でも下記に示す通り半導体レーザの特 長が発揮されている。

1) ウォーミングアップ時間が短い。

2)メンテナンスフリーである。

3) $\mathrm{AC} 100 \mathrm{~V}$ 仕様であり通常のコンセントからの電 源供給での使用が可能。

4）水やガス等の配管の必要がなく, 移動が自由であ る。

\section{4. 特 性}

半導体レーザに期待される特性は(1)安定した出力, 波 長のレーザ光が得られる。(2)半値幅の㹨いシャープな波 長が得られる。(3波長の温度依存性があり容易に波長制 御が行える等である。以下，今回開発した半等体レーザ 装置のそ机ぞれの特性につき紹介する。

\section{1 出力, 波長特性}

一般的に半導体レーザ素子は, 熱に弱く, 波長の温度 依存性がある。従って，熱破壊を防止する目的でレーザ 素子を冷却し過熱を防いだり，所定の波長を得るための 温度コントロールが必要である。一方, レーザ光出力の 安定化を図るためにレーザ素子内部に取り付けてある フォトセンサーによりレーザ光強度を常にモニターし，

APC回路 (Automatic Power Control) にフィード バックすることにより出力のコントロールを行っている。 図 5 は半導体レーザの運転時における波長と出力の状態 を示したものである。図中，(1が装置の電源投入ポイン トで, 投入と同時に温度コントロール装置が作動し波長 制御が開始される。投入後約 3 分で目標とする664nm のレーザ光が得られている。(2)はレーザ照射開始ポイン 


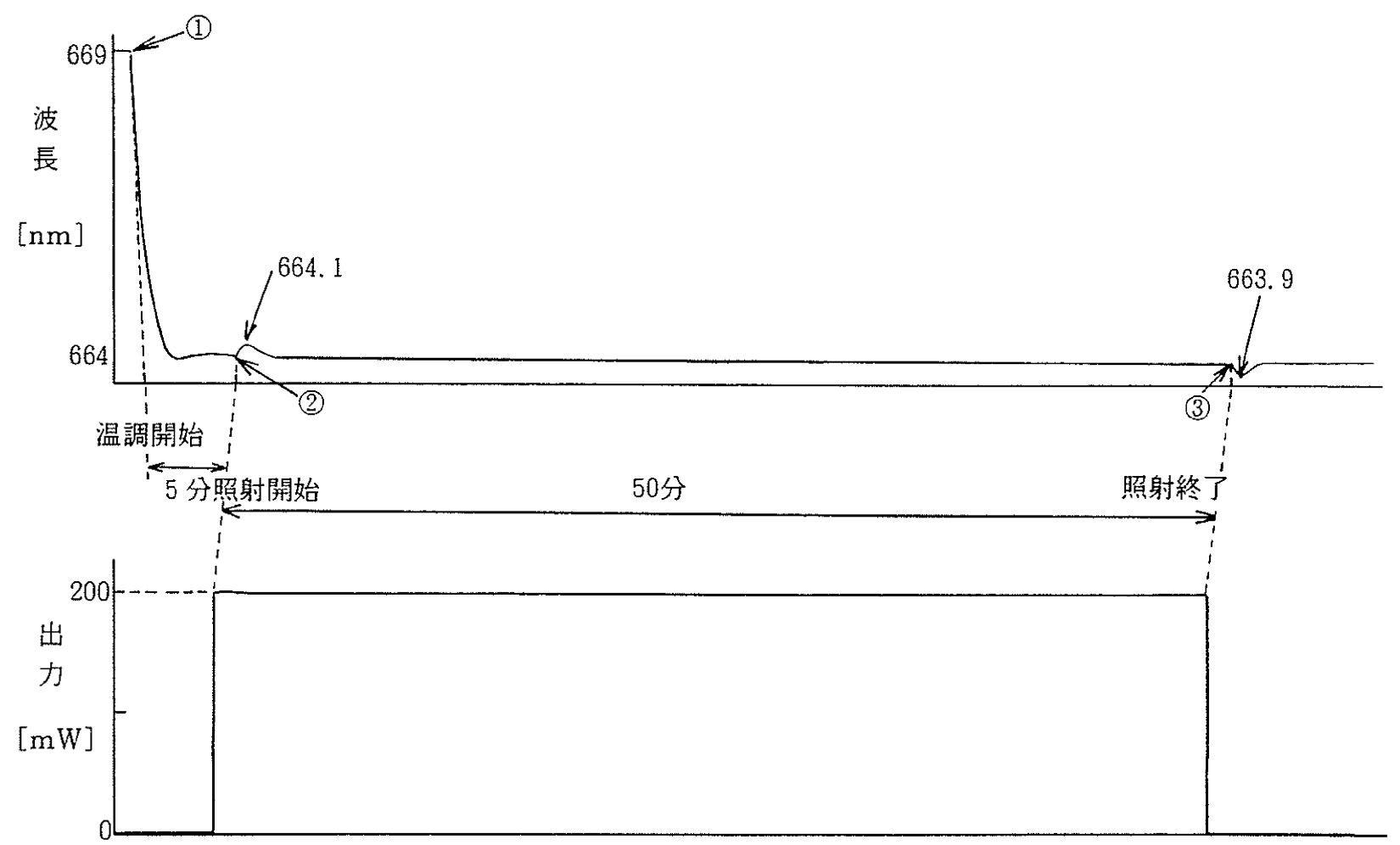

図 5 波長・出力の安定性

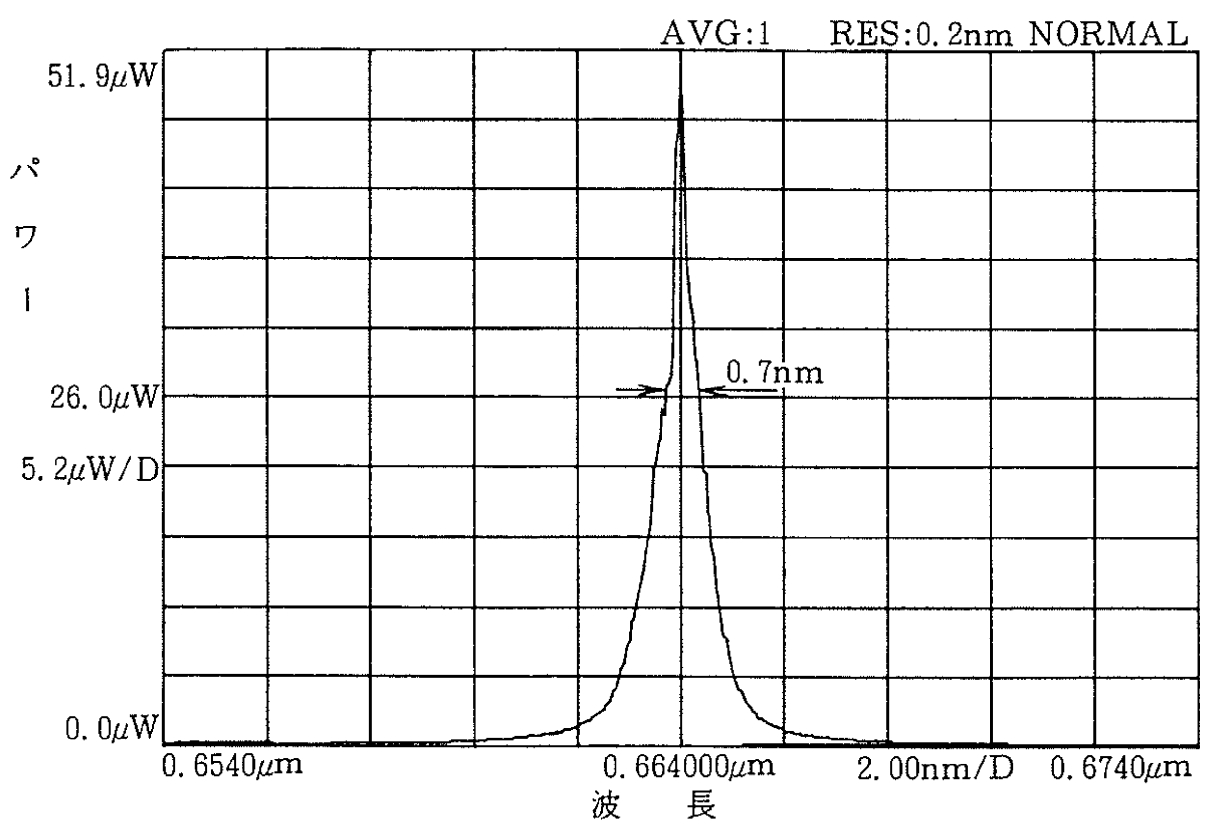

図6 波長スペクトル

トである。急激な負荷変動に伴い半導体レーザの温度コ ントロールが一時的に不安定になり僅かな波長变動が観 察される。(3はレーザ照射停止ポイントである。(2)上同 様に僅かな波長变動が観察される。しかしながら何れの 変動も0.1nm程度のものでありPDT効果に影響を及ぼ すものではない。出力についても全く変動がない安な 特性を示している。

\section{2 波長特性}

本装㯰のレーザ光の波長スペクトルを図 6 に示す。ス
ペクトルの分布状態を半値幅で（最大分布強度の $1 / 2$ 值 におけるスペクトル幅）表現するならば $1 \mathrm{~nm}$ 以下であ り，当該波長が得られる他の手段，例えば色素レーザ上 比較して格段にシャープな波長スペクトルであるといえ る。このことは，PDTにとっては照射エネルギの有効 活用という意味で大きなプラス要因となる。

\section{3 波長の温度依存性}

半体レーザの温度一波長特性を図 7 に示す。平均的 には0.2nm/degの依存性があり温度コントロールの精 


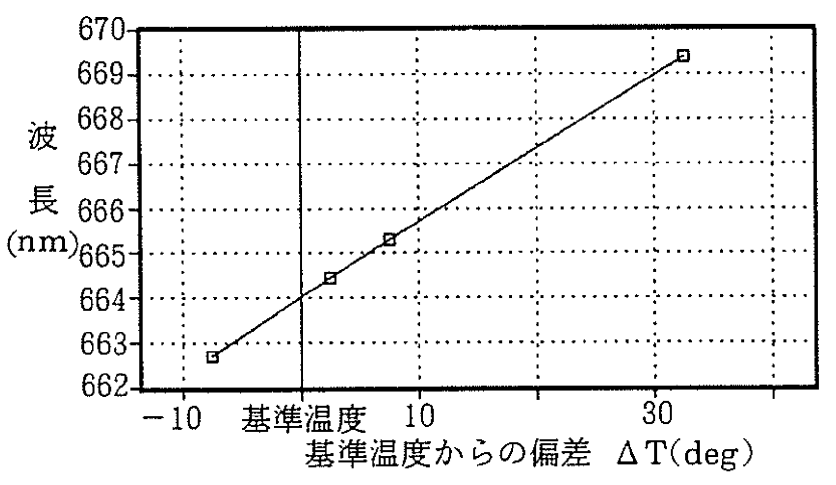

図 7 波長の温度依存性

度によっては正確に目標波長を得ることが可能である。

\section{5. 考 察}

以上の結果から分かるように, 本半導体レーザ装㯰で 得られるレーザ光は出力の安定性, 波長の安定性及び有 効性等何れもPDTに必要とされる条件を十分に満たし た内容になっている。また，664nmという波長は，へ モグロビンの吸収波長帯域から長波長側へ外れた波長で あり，例えば他の光感受性物質であるへマトポルフィリ ン誘導体の吸収帯波長 $630 \mathrm{~nm}$ と比較して組織深達性に 優れていることが容易に推察され，より深部の治療の可 能性が期待される。

一方, 東京医科大学で行われた本半導体レーザ装置上 光感受性物質であるNPe6を使用した担癌マウスによる 動物実験 長性能と併せ臨床での高い有効性が期待される。

\section{6. 結 論}

$\mathrm{PDT}$ 用の半導体レーザ装置の開発に取り組み，小型 ・軽量で操作がしやすく, 高い治潦効果か期待できる半 導体レーザ装置を開発することができた。

\section{文 献}

1) 加藤治文 : 光線力学的反応と癌の診断と治療。第 1 2 回日本レーザ医学会大会論文集 : 5-10，1992

2) Katsuo Aizawa, Tetsuya Okunaka, Takuzo Ohtani, Harubumi Kato, et. al, : LOCALIZA TION OF MONO-L-ASPARTYL CHLORIN e6 (NPe6)IN MOUSE TISSUES. Photochemistry and Photobiology, Vol. 46, No.5, : 789-793, 1987.

3) 勝海東一郎，奥仲哲弥，會沢勝夫，加藤治文，金田 明他：半導体レーザとNPe6を用いた光線力学的治 療（PDT）の検討。第14回日本レーザ医学会大会 論文集：347-350，1993 